\title{
Antimicrobial properties of hydrophobic compounds in garlic: Allicin, vinyldithiin, ajoene and diallyl polysulfides (Review)
}

\author{
MASATO NAKAMOTO, KAYO KUNIMURA, JUN-ICHIRO SUZUKI and YUKIHIRO KODERA \\ Central Research Institute, Wakunaga Pharmaceutical Co., Ltd., Akitakata-shi, Hiroshima 739-1195, Japan
}

Received August 9, 2019; Accepted September 26, 2019

DOI: $10.3892 /$ etm.2019.8388

\begin{abstract}
Allium plants, such as garlic, onion and leek have long been known to be effective in the therapy of infectious diseases. In particular, garlic has a greater antimicrobial activity than other Allium plants as it contains several hydrophobic antimicrobial compounds, such as allicin, vinyldithiins, ajoenes and diallyl polysulfides. Allicin is a characteristic sulfur-containing compound found in raw garlic produced from alliin and exhibits antimicrobial activity against both Gram-positive and Gram-negative bacteria. In addition, allicin has been reported to inhibit the biofilm formation of bacteria, which is a major cause of bacterial resistance to the antibiotic treatment of infections, by regulating quorum sensing in microorganisms. Other hydrophobic compounds also have similar inhibitory effects on bacteria as allicin. These biological properties of garlic-derived hydrophobic compounds can be used to enhance the effects of existing drugs and may thus be used in the treatment of infections, such as by preventing drug resistance through the inhibition of biofilm formation. In this review, we summarize the effects of hydrophobic compounds of garlic on bacteria.
\end{abstract}

\section{Contents}

1. Introduction

2. Antimicrobial activity of hydrophobic compounds in garlic

3. Effects of sulfur compounds on biofilm formation and quorum sensing

4. Conclusion

Correspondence to: Masato Nakamoto, Central Research Institute, Wakunaga Pharmaceutical Co., Ltd., 1624 Shimokotachi, Koda-cho, Akitakata-shi, Hiroshima 739-1195, Japan

E-mail: nakamoto_ms@wakunaga.co.jp

Abbreviations: $\mathrm{DAS}_{\mathrm{n}}$, diallyl polysulfides; $\mathrm{DAS}_{1}$, diallyl sulfide; $\mathrm{DAS}_{2}$, diallyl disulfide; $\mathrm{DAS}_{3}$, diallyl trisulfide; $\mathrm{QS}$, quorum sensing

Key words: garlic, hydrophobic compound, antimicrobial activity, biofilm

\section{Introduction}

Recently, the spread of drug-resistant bacteria has become a serious global concern in the therapy of infectious diseases. A number of antibiotics have been developed and used to treat infectious diseases; however, the increased frequency in the use of such antibiotics has led to changes in bacterial characteristics, with bacteria acquiring drug-resistant ability through the mutations of drug-target molecules, the overexpression of efflux pumps, changes in the composition of the cell membrane, the production of metabolizing enzymes and biofilm formation (1). Among these, the biofilm comprises a large community and aggregation of bacteria and its formation protects microbial cells from antibiotics and immune cells. The composition of biofilm is mainly water and extracellular polymeric substances (EPS), such as proteins, DNA, RNA and polysaccharides $(1,2)$. The production of EPS is regulated by quorum sensing (QS), which represents cell-to-cell communication in bacteria and is controlled by chemical signaling molecules, such as $\mathrm{N}$-acyl-L-homoserine lactones (AHLs) $(3,4)$. Thus, QS plays a crucial role in biofilm formation. The biofilm formation of bacteria has been reported to be associated with chronic infections; therefore, an increase in biofilm-forming bacteria is a serious issue, not only in the medical field, but also in a number of industrial fields and facilities. Therefore, the discovery and development of drugs to combat the formation of biofilm is an important approach for the fight against drug-resistant infections.

Garlic (Allium sativum L.) has been used as not only a food, but also as a remedy for several diseases, such as cardiovascular diseases and cancer (5-7). In addition, garlic has long been used in the treatment of infectious diseases, as described in the 9th century literary book entitled ure 'Bald's Leechbook'. A remedy termed Bald's eye salve for stye that is caused by Staphylococcus aureus (S. aureus) infection was prepared by the alcoholic extraction of garlic, onion or leek in a brass pot $(7,8)$. Fuchs et al demonstrated the antimicrobial activity of Bald's eye salve against $S$. aureus and Pseudomonas aeruginosa, including the multidrug-resistant phenotype and identified allicin as the principal antimicrobial compound in Bald's eye salve formulation. Allicin may greatly contributed to the treatment of stye in that era (7). On the other hand, allicin is chemically unstable and rapidly disappears when it comes into contact with body fluids $(9,10)$. Therefore, it is difficult for allicin to reach the infected sites of 
the body as an intact form. Recent studies have demonstrated that sulfur-containing compounds derived from garlic, such as diallyl disulfide $\left(\mathrm{DAS}_{2}\right)$ and ajoene, inhibit biofilm formation and the QS of bacteria, even though the antimicrobial activities of these compounds are lower than those in medical antibiotics used in clinical settings (11-16). Furthermore, Slachmuylders et $a l$ and others have demonstrated that some natural products, which exert an inhibitory effect on biofilm formation, have antibiotic-potentiating activity (17-20).

In this review, we focus on the antimicrobial activity of sulfur-containig compounds derived from garlic and describe their chemical and biological properties, including their inhibitory effect on bacterial biofilm formation.

\section{Antimicrobial activity of hydrophobic compounds in garlic}

Various hydrophobic antimicrobial compounds have been isolated from garlic and their structures are illustrated in Fig. 1. Among these compounds, allicin is considered to play a central role in the biological activity of garlic. However, allicin is unstable and tends to be converted into various compounds, such as ajoenes and diallyl polysulfides $\left(\right.$ DAS $\left._{n}\right)$, which have been reported to exhibit antimicrobial activity. In this section, we describe the chemical and biological properties of hydrophobic compounds in garlic and its preparation, exhibiting antimicrobial activity.

Allicin. Allicin is the most abundant and characteristic sulfur-containing compound in raw garlic. It is produced from alliin (21). Allicin has been shown to exhibit broad-spectrum antimicrobial activity against Gram-positive and -negative bacteria, including multidrug-resistant bacteria (22-26). In addition, allicin has been shown to possess antiviral, anti-fungal and anti-parasitic activity $(27,28)$. It has been reported that allicin exhibits antimicrobial activity by the $S$-allylmercapto modification of thiol-containing proteins in bacteria, which leads to lethal events, including the reduction of glutathione levels, the induction of protein aggregation and the inactivation of crucial enzymes (29). Reiter et al reported that allicin vapour exhibited antimicrobial activity against lung pathogenic bacteria (30). Additionally, topical treatment with allicin has been shown to improve skin infection caused by methicillin-resistant $S$. aureus (MRSA) (31). However, allicin is unstable and has been shown to be decomposed or metabolized within a few seconds in the blood (10). Therefore, the use of allicin may be limited to direct inhalation or external medicine due to its instability.

Vinyldithiins. Vinyldithiins that contain 2-vinyl-4H-1,2-dithiin and 3-vinyl-4H-1,3-dithiin are converted from one allicin molecule $(32,33)$. These compounds are characteristic sulfur-containing compounds in garlic oil macerate products (33). Vinyldithiins are known to have several biological activities, such as anti-obesity activity (34); however, they have no antimicrobial activity (35).

Ajoenes. Ajoenes ( $Z$-ajoene and $E$-ajoene) are also characteristic sulfur-containing compounds in garlic oil macerate products. Both ajoenes are converted from 3 allicin molecules (21). The antimicrobial activity of ajoenes has been

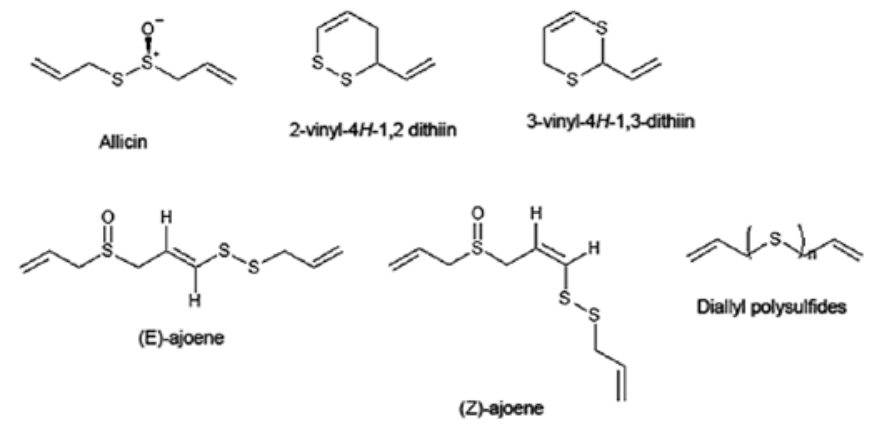

Figure 1. Hydrophobic compounds in garlic.

evaluated by several groups. Yoshida et al examined activity of ajoenes against Gram-positive and -negative bacteria and found that MIC values were 5-20 $\mu \mathrm{g} / \mathrm{ml}$ for Gram-positives and $100-160 \mu \mathrm{g} / \mathrm{ml}$ for Gram-negatives. They also indicated that $Z$-ajoene had a slightly greater activity than $E$-ajoene (36). An additional antimicrobial study of ajoenes against 3 strains of $H$. pylori demonstrated that the antimicrobial activities of both forms were similar i.e., $15-20 \mu \mathrm{g} / \mathrm{ml}$ for the $Z$-form and $25 \mu \mathrm{g} / \mathrm{ml}$ for the $E$-form (37). Ajoenes are also active against fungi, such as Aspergillus niger and Candida albicans $(38,39)$. Thus, ajoenes seem to be potent antimicrobial compounds; however, these compounds rapidly disappear after being mixed with the blood, as the case with allicin (10).

$D A S_{n} . \mathrm{DAS}_{\mathrm{n}}$ are major components of garlic oil, which are produced from allicin during the processing of garlic oil by the steam distillation method (40). Sulfur atom numbers of $\mathrm{DAS}_{\mathrm{n}}$ in garlic oil vary from 1 to 9 , depending on the production conditions. Generally, tri- and tetra-sulfur compounds are abundantly present (40). $\mathrm{DAS}_{\mathrm{n}}$ have limited antimicrobial activity against Gram-positive bacteria, including drug-resistant bacteria (41). Their antimicrobial activities depend on the number of sulfur atoms in the molecules and are in the order of diallyl tetrasulfide $\left(\mathrm{DAS}_{4}\right)>$ diallyl trisulfide $\left(\mathrm{DAS}_{3}\right)>$ $\mathrm{DAS}_{2}>$ diallyl sulfide $\left(\mathrm{DAS}_{1}\right)$ (12). Therefore, $\mathrm{DAS}_{\mathrm{n}}$ containing a higher number of sulfur atom than 5 may have more potent activity against bacterial pathogens.

Antimicrobial activity of compounds without sulfur atom derived from garlic. Matsuura et al isolated new furostanols termed proto-eruboside-B and satiboside-B from a crude glycoside fraction of garlic. They also found that these saponins transform into spinostanol form by endogenous $\beta$-glucosidase during processing period $(42,43)$. Notably, spinostanol from eruboside-B inhibits the growth of Candida albicans, whereas furostanol from proto-eruboside-B, does not (44). Kodera et al isolated a phenolic antimicrobial compound, 3-hydroxy5-methoxy-6-methyl-2-n-pentyl-4H-pyran-4-one, termed allixin (45). This compound was phytoalexin; however, the antimicrobial activity was very low.

\section{Effects of sulfur compounds on biofilm formation and quorum sensing}

Bacteria have a barrier system, biofilm formation, which inhibits the entry of disinfectants, antibiotics and host 
immune molecules into the bacterial cells and is a major cause of the drug-resistance of bacteria (44). In addition, QS molecules, such as AHL regulate biofilm formation, intercellular communication, bacterial population and other processes $(3,4,11,46)$. The inhibition of biofilm formation and QS has been studied in various scientific and technological fields. Certain natural products have been reported to provide effective resources for the inhibition of biofilm formation. Rasmussen et al performed screening to identify QS inhibitors (QSIs) by using a novel genetic system and found that toluene extract of garlic inhibited biofilm formation (13). This result suggests that hydrophobic compounds extracted from garlic might have activity as a QSI (47). Allicin prevents biofilm formation by inhibiting early bacterial adhesion and EPS secretion $(42,48,49)$. In addition, allicin inhibits the secretion of virulence factors by regulating QS (50). Ajoene regulates biofilm formation by blocking the QS-induced production of virulence factors $(51,52)$. $\mathrm{DAS}_{2}$ inhibits the biofilm formation of Pseudomonas spp by inhibiting the production of virulence factors via the regulation of QS at the concentration of $0.16-1.28 \mathrm{mg} / \mathrm{ml}$ with no effects on microbial growth (44). In addition, $\mathrm{DAS}_{2}$ inhibits the formation of biofilm by suppressing the expression of key QS-related genes (44). Moreover, in the S. aureus QS system, a peptidic compound having a thioester group acts as an autoinducer (53). It is expected that $\mathrm{DAS}_{2}$ may also inhibit QS through the reaction with the thioester group of the autoinducer. These hydrophobic compounds may contribute to the reduction of undesirable impacts of microorganisms on humans and they can be expected to suppress the development of drug resistance due to biofilm formation of bacteria.

\section{Conclusion}

Various hydrophobic compounds derived from garlic and its preparations have broad-spectrum antimicrobial activities. In particular, allicin and its derivatives have been studied extensively as antimicrobial active ingredients and have shown the inhibitory activity of biofilm formation by inhibiting QS. However, these compounds are unstable and could not be used against systemic infections. Therefore, the development of allicin derivatives with sufficient stability may lead to the development of superior compounds with greater antimicrobial activity and more potent inhibitory activity against biofilm formation for the treatment of drug-resistant bacteria.

\section{Acknowledgements}

The authors would like to thank Dr Takami Oka of Wakunaga Pharmaceutical Co., Ltd. for his helpful advice, encouragement and critical reading of the manuscript.

\section{Funding}

No funding was received.

\section{Availability of data and materials}

Not applicable.

\section{Authors' contributions}

$\mathrm{MN}$ and YK conceived this review. MN, KK and JIS analyzed the relevant literature. MN wrote the first draft of the manuscript and produced the figures. KK, JIS and YK critically revised the manuscript. All authors have reviewed and approved the final manuscript.

\section{Ethics approval and consent to participate}

Not applicable.

\section{Patient consent for publication}

Not applicable.

\section{Competing interests}

The authors declare that they have no competing interests.

\section{References}

1. López D, Vlamakis H and Kolter R: Biofilms. Cold Spring Harb Perspect Biol 2: a000398, 2010.

2. Muhsin J, Ufaq T, Tahir H and Saadia A: Bacterial biofilm: its composition, formation and role in human infections. J Microbiol Biotechnol 4: 1-14, 2015.

3. Bassler BL: Small talk. Cell-to-cell communication in bacteria. Cell 109: 421-424, 2002.

4. Nadell CD, Xavier JB, Levin SA and Foster KR: The evolution of quorum sensing in bacterial biofilms. PLoS Biol 6: e14, 2008.

5. Rahman K and Lowe GM: Garlic and cardiovascular disease: A critical review. J Nutr 136: 736S-740S, 2006.

6. Roy N, Davis S, Narayanankutty A, Nazeem P, Babu T, Abida P. Valsala $\mathrm{P}$ and Raghavamenon AC: Garlic phytocompounds possess anticancer activity by specifically targeting breast cancer biomarkers-an in silico study. Asian Pac J Cancer Prev 17: 2883-2888, 2016.

7. Fuchs AL, Weaver AJ Jr, Tripet BP, Ammons MCB, Teintze M and Copié V: Characterization of the antibacterial activity of Bald's eyesalve against drug resistant Staphylococcus aureus and Pseudomonas aeruginosa. PLoS One 13: e0208108, 2018.

8. Zwergal A: Beitrag zur Kenntnis der Inhaltsstoffe des Knoblauchs, Allium sativum L. Chem Abstr 47: 3224, 1952. (In German)

9. Lawson LD and Wang ZJ: Pre-hepatic fate of the organosulfur compounds derived from garlic (Allim sativum). Planta Med 59 (S1): A688-A689, 1993.

10. Freeman F and Kodera Y: Garlic chemistry: Stability of S-(2-propyl) 2-propen-1-sulfinothioate (allicin) in blood, solvents, and stimulated physiological fluids. J Agric Food Chem 43: 2332-2338, 1995.

11. Li WR, Ma YK, Shi QS, Xie XB, Sun TL, Peng H and Huang XM: Diallyl disulfide from garlic oil inhibits Pseudomonas aeruginosa virulence factors by inactivating key quorum sensing genes. Appl Microbiol Biotechnol 102: 7555-7564, 2018.

12. Tsao S and Yin M: In vitro activity of garlic oil and four diallyl sulphides against antibiotic-resistant Pseudomonas aeruginosa and Klebsiella pneumoniae. J Antimicrob Chemother 47: 665-670, 2001.

13. Rasmussen TB, Bjarnsholt T, Skindersoe ME, Hentzer M, Kristoffersen P, Köte M, Nielsen J, Eberl L and Givskov M: Screening for quorum-sensing inhibitors (QSI) by use of a novel genetic system, the QSI selector. J Bacteriol 187: 1799-1814, 2005.

14. Gowrishankar S, Kamaladevi A, Balamurugan $\mathrm{K}$ and Pandian SK: In vitro and in vivo biofilm characterization of methicillin-resistant staphylococcus aureus from patients associated with pharyngitis infection. BioMed Res Int 2016: 1289157, 2016.

15. Corrigan RM, Rigby D, Handley P and Foster TJ: The role of Staphylococcus aureus surface protein SasG in adherence and biofilm formation. Microbiology 153: 2435-2446, 2007. 
16. Alabdullatif $M$ and Ramirez-Arcos S: Biofilm-associated accumulation-associated protein (Aap): A contributing factor to the predominant growth of Staphylococcus epidermidis in platelet concentrates. Vox Sang 114: 28-37, 2019.

17. Slachmuylders L, Van Acker H, Brackman G, Sass A, Van Nieuwerburgh F and Coenye T: Elucidation of the mechanism behind the potentiating activity of baicalin against Burkholderia cenocepacia biofilms. https://doi.org/10.1371/journal. pone.0190533

18. Yu C, Li X, Zhang N, Wen D, Liu C and Li Q: Inhibition of biofilm formation by D-tyrosine: Effect of bacterial type and D-tyrosine concentration. Water Res 92: 173-179, 2016.

19. Kariu T, Nakao R, Ikeda T, Nakashima K, Potempa J and Imamura T: Inhibition of gingipains and Porphyromonas gingivalis growth and biofilm formation by prenyl flavonoids. J Periodontal Res 52: 89-96, 2017.

20. Hasibul K, Nakayama-Imaohji H, Hashimoto M, Yamasaki H, Ogawa T, Waki J, Tada A, Yoneda S, Tokuda M, Miyake M and Kuwahara T: D-Tagatose inhibits the growth and biofilm formation of Streptococcus mutans. Mol Med Rep 17: 843-851, 2018.

21. Block E: The chemistry of garlic and onions. Sci Am 252: 114-119, 1985.

22. Cavallito CJ and Bailey JH: Allicin, antibacterial principle of Allium sativum. I. Islation, physical properties, and antibacterial action. J Am Chem Soc 66: 1950-1951, 1944.

23. Wu X, Santos RR and Fink-Gremmels J: Analyzing the antibacterial effects of food ingredients: Model experiments with allicin and garlic extracts on biofilm formation and viability of Staphylococcus epidermidis. Food Sci Nutr 3: 158-168, 2015

24. Wallock-Richards D, Doherty CJ, Doherty L, Clarke DJ, Place M, Govan JR and Campopiano DJ: Garlic revisited: Antimicrobial activity of allicin-containing garlic extracts against Burkholderia cepacia complex. PLoS One 9: e112726, 2014.

25. Feldberg RS, Chang SC, Kotik AN, Nadler M, Neuwirth Z, Sundstrom DC and Thompson NH: In vitro mechanism of inhibition of bacterial cell growth by allicin. Antimicrob Agents Chemother 32: 1763-1768, 1988

26. Loi VV, Huyen NTT, Busche T, Tung QN, Gruhlke MCH Kalinowski J, Bernhardt J, Slusarenko AJ and Antelmann H: Staphylococcus aureus responds to allicin by global $S$-thioallylation-Role of the $\mathrm{Brx} / \mathrm{BSH} / \mathrm{YpdA}$ pathway and the disulfide reductase MerA to overcome allicin stress. Free Radic Biol Med 139: 55-69, 2019.

27. Weber ND, Andersen DO, North JA, Murray BK, Lawson LD and Hughes BG: In vitro virucidal effects of Allium sativum (garlic) extract and compounds. Planta Med 58: 417-423, 1992.

28. Getti GTM and Poole PL: Allicin causes fragmentation of the peptidoglycan coat in Staphylococcus aureus by effecting synthesis and aiding hydrolysis: A determination by MALDI-TOF mass spectrometry on whole cells. J Med Microbiol 68: 667-677, 2019.

29. Müller A, Eller J, Albrecht F, Prochnow P, Kuhlmann K, Bandow JE, Slusarenko AJ and Leichert LI: Allicin induces thio stress in bacteria through $\mathrm{S}$-alylmercapto modification of protein cysteines. J Biol Chem 291: 11477-90, 2016.

30. Reiter J, Levina N, van der Linden M, Gruhlke M, Martin C and Slusarenko AJ: Diallylthiosulfinate (allicin), a volatile antimicrobial from garlic (Allium sativum), kills human lung pathogenic bacteria, including MDR strains, as a vapor. Molecules 22: E1711, 2017.

31. Sharifi-Rad J, Hoseini Alfatemi S, Sharifi Rad M and Iriti M Antimicrobial synergic effect of allicin and silver nanoparticles on skin infection caused by methicillin-resistant staphylococcus aureus spp. Ann Med Health Sci Res 4: 863-8, 2014.

32. Amagase $\mathrm{H}$ : Clarifying the real bioactive constituents of garlic. $\mathrm{J}$ Nutr 136 (Suppl): 716S-725S, 2006

33. Block E: Garlic and Other Alliums: The Lore and the Science. The Royal Society of Chemistry, Cambridge, UK, 2010.

34. Keophiphath M, Priem F, Jacquemond-Collet I, Clément K and Lacasa D: 1,2-Vinyldithiin from garlic inhibits differentiation and inflammation of human preadipocytes. J Nutr 139: 2055-2060, 2009.

35. Hermes Robert E: Antithrombogenic and antibiotic composition and methods of preparation thereof: US Patent 4917921: Filed April 20, 1988; issued January 25, 1990.
36. Yoshida H, Iwata N, Katsuzaki H, Naganawa R, Ishikawa K, Fukuda H, Fujino T and Suzuki A: Antimicrobial activity of a compound isolated from an oil-macerated garlic extract. Biosci Biotechnol Biochem 62: 1014-1017, 1998.

37. Ohta R, Yamada N, Kaneko H, Ishikawa K, Fukuda H, Fujino T and Suzuki A: In vitro inhibition of the growth of Helicobacter pylori by oil-macerated garlic constituents. Antimicrob Agents Chemother 43: 1811-1812, 1999.

38. Maluf ML, Takahachi G, Svidzinski TI,XanderP, Apitz-Castro R, Bersani-Amado CA and Cuman RK: Antifungal activity of ajoene on experimental murine paracoccidioidomycosis. Rev Iberoam Micol 25: 163-166, 2008.

39. Yoshida S, Kasuga S, Hayashi N, Ushiroguchi T, Matsuura H and Nakagawa S: Antifungal activity of ajoene derived from garlic. Appl Environ Microbiol 53: 615-617, 1987.

40. Satyal P, Craft JD, Dosoky NS and Setzer WN: The chemical compositions of the volatile oils of garlic (allium sativum) and wild garlic (Allium vineale). Foods 6: e63, 2017.

41. Koch HP and Lawson LD (eds): The Science and Therapeutic Application of Allium Sativum $\mathrm{L}$ and Related Species. 2nd edition. Williams and Wilkins, Baltimore, MD, USA, 1996.

42. Matsuura $H$, Ushiroguchi T, Itakura $\mathrm{Y}$, Hayashi $\mathrm{N}$ and Fuwa $\mathrm{T}$ : A furostanol glycoside from garlic, bulbs of Allium sativum $\mathrm{L}$. Chem Pharm Bull (Tokyo) 36: 3659-3663, 1988.

43. Matsuura H, Ushiroguchi T, Itakura Y and Fuwa T: Further studies on steroidal glycosides from bulbs, root and leaves of Allium sativum L. Chem Pharm Bull (Tokyo) 37: 2741-2743, 1989.

44. Høiby N: A short history of microbial biofilms and biofilm infections. APMIS 125: 272-275, 2017

45. Kodera Y, Matsuura H, Yoshida S, Sumida T, Itakura Y, Fuwa T and Nishino H: Allixin, a stress compound from garlic. Chem Pharm Bull (Tokyo) 37: 1656-1658, 1989.

46. Novick RP: Autoinduction and signal transduction in the regulation of staphylococcal virulence. Mol Microbiol 48: 1429-1449, 2003.

47. Persson T, Hansen TH, Rasmussen TB, Skinders $\varnothing$ ME, Givskov $\mathrm{M}$ and Nielsen J: Rational design and synthesis of new quorum-sensing inhibitors derived from acylated homoserine lactones and natural products from garlic. Org Biomol Chem 3: 253-262, 2005.

48. Lihua L, Jianhuit W, Jialini Y, Yayin L and Guanxin L: Effects of allicin on the formation of Pseudomonas aeruginosa biofinm and the production of quorum-sensing controlled virulence factors. Pol J Microbiol 62: 243-251, 2013.

49. Ranjbar-Omid M, Arzanlou M, Amani M, Shokri Al-Hashem SK, Amir Mozafari N and Peeri Doghaheh H: Allicin from garlic inhibits the biofilm formation and urease activity of Proteus mirabilis in vitro. FEMS Microbiol Lett 362: fnv049, 2015.

50. Xu Z, Zhang H, Yu H, Dai Q, Xiong J, Sheng H, Qiu J, Jiang L, Peng J, He X, et al: Allicin inhibits Pseudomonas aeruginosa virulence by suppressing the $r h l$ and pqs quorum-sensing systems. Can J Microbiol 65: 563-574, 2019.

51. Jakobsen TH, van Gennip M, Phipps RK, Shanmugham MS, Christensen LD, Alhede M, Skindersoe ME, Rasmussen TB, Friedrich K, Uthe F, et al: Ajoene, a sulfur-rich molecule from garlic, inhibits genes controlled by quorum sensing. Antimicrob Agents Chemother 56: 2314-2325, 2012.

52. Jakobsen TH, Warming AN, Vejborg RM, Moscoso JA, Stegger M, Lorenzen F, Rybtke M, Andersen JB, Petersen R, Andersen PS, Nielsen TE, Tolker-Nielsen T, Filloux A, Ingmer H and Givskov M: A broad range quorum sensing inhibitor working through sRNA inhibition. Sci Rep 7: 9857, 2017.

53. Vasquez JK, Tal-Gan Y, Cornilescu G, Tyler KA and Blackwell HE: Simplified AIP-II peptidomimetics are potent inhibitors of Staphylococcus aureus AgrC quorum sensing receptors. Chembiochem 18: 413-423, 2017.

This work is licensed under a Creative Commons Attribution-NonCommercial-NoDerivatives 4.0 International (CC BY-NC-ND 4.0) License. 